\title{
KINERJA PEGAWAI, KOMITMEN ORGANISASI DALAM PRODUKTIVITAS KERJA PEGAWAI
}

\author{
Oleh: \\ Intan Nursanti \\ Pusat Pengembangan dan Pemberdayaan Pendidik dan Tenaga Kependidikan \\ Taman Kanak-Kanak dan Pendidikan Luar Biasa \\ (e-mail : Intan 332233@yahoo.com)
}

\begin{abstract}
ABSTRAK
Penelitian ini bertujuan untuk mengetahui berapa besar pengaruh kinerja pegawai dan komitmen organisasi terhadap produktivitas kerja pegawai. Metode penelitian yang digunakan yaitu metode deskriptif dengan pendekatan kuantitatif. Populasi penelitian ini adalah seluruh pegawai negeri sipil di Unit kerja pengembangan tenaga pendidik sejumlah 137 orang. Sampel yang digunakan sebanyak 58 orang sesuai perhitungan dengan rumus Slovin. Instrumen yang digunakan berupa angket mengenai kinerja pegawai, komitmen organisasi dan produktivitas kerja pegawai. Hasil penelitian menunjukkan kontribusi kinerja pegawai lebih besar daripada komitmen organisasi terhadap produktivitas kerja pegawai. Secara simultan keduanya berpengaruh sangat kuat dan signifikan terhadap produktivitas kerja pegawai.
\end{abstract}

Kata Kunci: Kinerja Pegawai, Komitmen Organisasi, Produktivitas Kerja

\section{ABSTRACT}

This study aims to determine how much influence employee performance and organizational commitment on employee work productivity. The research method used is descriptive method with a quantitative approach. The population of this study was 137 civil servants at the teachers development unit. The sample used was 58 people according to the calculation with the Slovin formula. The instruments used were questionnaires regarding employee performance, organizational commitment and employee work productivity. The results of the study show that the contribution of employee performance is greater than the organizational commitment to employee work productivity. Simultaneously both have a very strong and significant effect on employee work productivity.

Keywords: Employee Performance, Organizational Commitment, Work Productivity

\section{PENDAHULUAN}

Dalam sebuah organisasi, baik publik maupun swasta, peran sumber daya manusia sangat penting. Hal ini dikarenakan sumber daya manusialah yang menjalankan roda organisasi tersebut. Baik atau tidaknya atau tinggi atau rendahnya produktivitas dan kinerja suatu organisasi sangat dipengaruhi oleh sumber daya manusia yang berada dalam organisasi tersebut. Oleh karena itulah, manajemen sumber daya manusia dalam sebuah organisasi mulai semakin diperhatikan.

Begitupula dengan Unit kerja pengembangan tenaga pendidik Bandung. Untuk meningkatkan produktivitas dan kinerja organisasi, Unit kerja pengembangan tenaga pendidik Bandung memerlukan sumber daya manusia yang tepat. Seperti yang dikemukakan oleh Yuniarsih dan Suwatno (2016), sumber daya manusia akan memberikan pengaruh langsung pada produktivitas kerja yang dilakukannya dan selanjutnya akan menentukan tingkat produktivitas kerja suatu organisasi atau perusahaan.

Saat ini diketahui bahwa produktivtas organisasi Unit kerja pengembangan tenaga pendidik sudah baik. Bisa dilihat dari capaian kegiatan pada tahun 2017 yang melebihi anggaran DIPA Unit kerja pengembangan tenaga pendidik Bandung. Sesuai dengan yang dikemukakan oleh Paul Mali (dalam Yuniarsih dan Suwatno, 2016, hlm. 157) bahwa produktivitas berkaitan dengan bagaimana menghasilkan atau meningkatkan hasil barang dan jasa setinggi mungkin dengan memanfaatkan segala sumber daya secara efisien. 
Sejalan dengan pendapat tersebut, Saputra dan Muhidin (2011), berpendapat bahwa konsep produktivitas kerja mengacu pada pendekatan sikap mental yang mempunyai semangat untuk melakukan peningkatan dan perbaikan. Hal ini diperjelas oleh Nawawi (1990, dalam Yuniarsih dan Suwatno, 2016) bahwa produktivitas kerja pegawai merupakan gambaran dedikasi, loyalitas, disiplin dan metode kerja yang dilakukan saat melaksanakan tugas dan beban kerja yang diberikan kepadanya.

Selain produktivitas, suatu organisasi akan dilihat juga bagaimana kinerja organisasinya. Kinerja menurut Prawirosentono (dalam Sinambela, 2012) adalah suatu hasil kerja yang dicapai oleh seseorang atau sekelompok orang dalam suatu organisasi, sesuai dengan wewenang dan tanggung jawab masing-masing, yang dilakukan dalam rangka mencapai tujuan organisasi.

Bila dilihat dari laporan kinerja pada tahun 2016 dan tahun 2017 serta berdasarkan tabel pengukuran pencapaian hasil program dan kegiatan dengan menggunakan rentang nilai capaian dan kategori capaian, maka dapat diambil kesimpulan bahwa Unit kerja pengembangan tenaga pendidik mempunyai akuntabilitas kinerja yang baik dengan kategori capaian kinerja yang sangat memuaskan pada tahun 2016 dan dengan kategori capaian sangat baik pada tahun 2017.

Untuk mencapai kinerja organisasi yang baik, tentunya didukung oleh kinerja pegawai yang baik pula. Menurut Wahyuddin (2006), faktorfaktor yang dapat mempengaruhi kinerja pegawai, antara lain motivasi, kepemimpinan, lingkungan kerja, disiplin kerja, budaya kerja, komunikasi, komitmen, jabatan, kualitas kehidupan kerja, pelatihan, kompensasi, kepuasan kerja, dan masih banyak yang lain.
Berdasarkan pasal 4 PP No. 46 Tahun 2011, penilaian prestasi kerja PNS dibagi dalam dua unsur, yaitu: (1) Sasaran Kerja Pegawai (SKP) merupakan rencana kerja dan target yang akan dicapai oleh seorang PNS dan dilakukan berdasarkan kurun waktu tertentu dengan bobot penilaian sebesar $60 \%$. Sasaran kerja pegawai meliputi beberapa aspek, yaitu: kuantitas, kualitas, waktu dan biaya; (2) Perilaku kerja merupakan setiap tingkah laku, sikap atau tindakan yang dilakukan oleh seorang PNS yang seharusnya dilakukan atau tidak dilakukan sesuai dengan ketentuan peraturan perundang-undangan yang berlaku dengan bobot penilaian sebesar $40 \%$. Adapun unsur perilaku kerja yang dinilai meliputi orientasi pelayanan, integritas, komitmen, disiplin, kerja sama dan kepemimpinan.

Adapun nilai capaian dan keterangannya, baik SKP maupun PPK PNS diatur dalam PP No. 46 Tahun 2011 dan dijelaskan lebih lanjut pada Perka BKN No. 1 Tahun 2013. Berdasarkan peraturan tersebut, maka dapat diambil kesimpulan bahwa kinerja pegawai di Unit kerja pengembangan tenaga pendidik sudah mencapai kriteria baik. Artinya menurut penilaian tersebut, pegawai Unit kerja pengembangan tenaga pendidik sudah memenuhi kewajiban SKP-nya pada tahun 2016 dan 2017, serta memiliki perilaku yang dinilai atasan langsung dalam kriteria baik.

Meskipun terdapat penurunan nilai dalam penilaian kinerja, akan tetapi selama masih dalam satu kriteria capaian hal tersebut dapat terjadi. Hal ini bisa disebabkan berbagai hal. Salah satunya kemungkinan adanya perbedaan jumlah PNS saat penilaian kinerja tersebut dilakukan, dimana banyak PNS yang sudah memasuki masa purnabakti. Selain itu, adanya system penilaian kinerja yang sudah komputerisasi memungkinkan penilaian kinerja yang lebih obyektif bila 
dibandingkan sebelumnya. Di samping itu, penilaian kinerja saat ini berdasarkan pada pencapaian target SKP tiap pegawai. Sehingga nilai pencapaiannya dapat berfluktuasi, bisa naik dan bisa turun. Akan tetapi, hasil penilaian kinerja ini tidak sejalan dengan nilai sikap pegawai yang sebenarnya di lapangan, baik dari sikap produktivitas kerja, kinerja dan komitmen. Salah satu indikatornya adalah dari disiplin kehadiran.

Sebagai lembaga diklat pemerintah, Unit kerja pengembangan tenaga pendidik menuntut pegawainya untuk memiliki disiplin kerja yang baik dan tinggi. Hal ini sesuai dengan PP No. 53 tahun 2010 tentang disiplin pegawai negeri sipil. Akan tetapi, disiplin kerja yang tinggi ini tidak terlihat dalam rekap kehadiran absensi pegawai pada tahun 2017.

Bila dilihat dari rekapitulasi kehadiran pegawai dalam kurun waktu 10 bulan di tahun 2017 rata-rata pegawai yang tidak hadir dengan tidak memiliki keterangan apapun sebanyak 32,5 orang tiap bulannya. Hal ini mengindikasikan bahwa dorongan disiplin kerja PNS di Unit kerja pengembangan tenaga pendidik masih kurang. Akan tetapi, ketidakhadiran tersebut tidak hanya menunjukkan adanya disiplin yang kurang saja.

Banyaknya pegawai yang tidak hadir menunjukkan adanya sikap komitmen organisasi yang tidak tinggi. Komitmen organisasi merupakan sikap kerja dalam mewujudkan keinginan, kemauan, dedikasi, loyalitas, dan/atau kepercayaan yang kuat dalam mewujudkan keinginan untuk tetap menjadi bagian anggota organisasi dengan mau menerima nilai dan tujuan organisasi dan bekerja atas nama dan untuk kepentingan organisasi (Kaswan, 2015).

Luthans (2011) yang menyatakan bahwa komitmen organisasi sebagai sikap kerja mempunyai dampak yang positif terhadap organisasi, dimana ditunjukkan dengan adanya hubungan positif komitmen organisasi terhadap kinerja tinggi, rendahnya pergantian karyawan dan rendahnya ketidakhadiran.

Selain dilihat dari tingkat kehadiran, perilaku komitmen juga dapat tercermin pada kesediaan pegawai dalam menyelesaikan pekerjaan, mempunyai keinginan untuk terus berada dalam organisasi, merasa lebih bahagia dan lebih produktif, serta memiliki tanggung jawab pada tugas yang didelegasikan kepada dirinya (Kaswan, 2015; Yuniarsih dan Suwatno, 2016).

Osa dan Amos (2014) mengemukakan bahwa komitmen organisasi memiliki dampak yang signifikan terhadap produktivitas karyawan dan dengan demikian meningkatkan kinerja dan efektivitas organisasi. Oleh karena itu, komitmen organisasi yang dimiliki oleh pegawai harus tinggi untuk mencapai kinerja dan produktivitas kerja yang tinggi pula.

\section{METODE PENELITIAN}

Metode penelitian yang digunakan adalah metode deskriptif dengan pendekatan kuantitatif. Penelitian ini dilakukan di Unit kerja pengembangan tenaga pendidik Bandung.

Populasi dalam penelitian ini adalah seluruh PNS yang bekerja pada Unit kerja pengembangan tenaga pendidik Bandung. Jumlah total dari populasi adalah 137 orang. Jumlah sampel yang digunakan dihitung dengan menggunakan rumus Slovin sebanyak 58 orang.

Penelitian ini menggunakan tiga instrumen sesuai jumlah variabel yang akan diteliti yaitu: kinerja pegawai, komitmen organisasi dan produktivitas kerja pegawai. 
Kinerja pegawai adalah fungsi atau hasil dari suatu pekerjaan yang dilaksanakan dalam periode waktu tertentu sesuai dengan peran dan tugas yang diberikan. Aspek dimensi yang dimaksud terdiri dari 1) kemampuan teknis, 2) kemampuan konseptual, 3) kemampuan hubungan interpersonal, 4) kehadiran, dan 5) ketepatan waktu.

Komitmen organisasi adalah seberapa besar tingkat keterikatan seorang pegawai terhadap organisasi tempatnya bekerja. Komitmen organisasi terdiri dari tiga macam, yaitu komitmen afektif, komitmen berkelanjutan dan komitmen normative.

Produktivitas adalah produktivitas kerja pegawai adalah sikap mental pegawai yang senantiasa berusaha untuk terus berkembang dan melakukan peningkatan perbaikan dalam menghadapi peran, tugas dan beban kerjanya sehingga menghasilkan suatu output kinerja yang tinggi. Aspek dimensi yang dimaksud terdiri dari 1) etos kerja; 2) kualitas kerja; 3) kuantitas jumlah kerja.

Teknik analisis data yang digunakan adalah analisis deskriptif dengan teknik Weighted Mean Score (WMS) untuk merangkum kecenderungan secara keseluruhan dalam data. Nilai yang digunakan untuk merepresentasikan kecenderungan tersebut adalah nilai rata-rata. Rumus rata-rata adalah sebagai berikut.

$$
\bar{X}=\frac{\sum X}{N} \ldots(1)
$$

Keterangan:
$\bar{X} \quad=$ Rata-rata skor responden

$\sum X \quad=$ Jumlah skor jawaban responden

$\mathrm{N}=$ Jumlah responden

Untuk mengetahui apakah ada pengaruh antara masing-masing variabel bebas yaitu kinerja pegawai dan komitmen organisasi terhadap variabel terikat yaitu produktivitas kerja pegawai, dilakukan uji hipotesis menggunakan analisis regresi linear sederhana dan regresi linear berganda. Regresi linear sederhana digunakan untuk menguji besarnya pengaruh variabel bebas Kinerja Pegawai (X1) terhadap Produktivitas Kerja pegawai (Y) serta pengaruh variabel bebas Komitmen Organisasi (X2) terhadap Produktivitas Kerja Pegawai (Y). Sedangkan regresi linear berganda digunakan untuk menguji besarnya pengaruh secara simultan (bersama-sama) antara variabel Kinerja Pegawai (X1) dan Komitmen Organisasi(X2) terhadap Produktivitas Kerja Pegawai (Y). Dari hasil analisis regresi dapat diketahui nilai koefisien korelasi ( $\mathrm{R}$ ) yang menunjukkan kuat atau lemahnya hubungan di antara variabel bebas dan variabel terikat yang diukur. Adapun besarnya persentase kontribusi variabel bebas terhadap variabel terikat ditunjukkan oleh nilai Adjusted R Square yang dikalikan dengan $100 \%=($ Adj. R2 $) \times 100 \%$. Nilai $\mathrm{R}$ berada pada rentang -1 dan 1 . Jika nilai $\mathrm{R}=-1$ maka korelasi dikatakan negatif sempurna. Sebaliknya jika $\mathrm{R}=1$ berarti korelasi sangat kuat (positif sempurna). Interpretasi nilai koefisien korelasi $\mathrm{R}$ disajikan pada tabel berikut.

Tabel 1

Interpretasi Koefisien Korelasi R 


\begin{tabular}{cc}
\hline Interval Koefisien Korelasi & Tingkat Hubungan \\
\hline $0,000-0,199$ & Sangat Rendah \\
$0,200-0,399$ & Rendah \\
$0,400-0,599$ & Cukup Kuat \\
$0,600-0,799$ & Kuat \\
$0,800-1,000$ & Sangat Kuat \\
\hline
\end{tabular}

\section{HASIL PENELITIAN}

Berdasarkan perhitungan deskriptif dengan menggunakan WMS, variabel kinerja pegawai masuk kategori tinggi sebesar 3,57, variabel komitmen organisasi masuk kategori tinggi sebesar 3,57 dan variabel produktivitas kerja pegawai masuk kategori tinggi sebesar 3,60. Pada variabel kinerja pegawai, dimensi kemampuan konseptual dan dimensi kemampuan hubungan interpersonal memperoleh nilai tertinggi, sedangkan dimensi kehadiran memperoleh nilai terendah. Pada variabel komitmen organisasi, dimensi komitmen normative memperoleh nilai tertinggi, sedangkan dimensi komitmen berkelanjutan memperoleh nilai terendah. Pada variabel produktivitas kerja, dimensi etos kerja memperoleh nilai tertinggi, sedangkan dimensi kuantitas jumlah kerja memperoleh nilai terendah.

Sebelum dilakukan pengujian hipotesis untuk menjawab pertanyaan penelitian, terlebih dahulu dilakukan uji asumsi klasik yang terdiri atas uji normalitas, uji linearitas, uji heteroskedastisitas, dan uji multikolinearitas. Uji normalitas dilakukan untuk melihat apakah nilai residual dari data yang dimiliki berdistribusi normal atau tidak. Pengujian residual berdistribusi normal dilakukan dengan uji Kolmogorov-Smirnov. Uji linearitas digunakan untuk melihat apakah antara variabel bebas dan variabel terikat bersifat linear. Uji heteroskedastisitas dilakukan untuk melihat apakah varian residual model regresi homogen atau paling tidak ada satu pengamatan yang memiliki varian yang berbeda. Uji heteroskedasitas yang digunakan adalah Uji Glejser. Uji multikolinearitas dilakukan untuk mengetahui apakah ada hubungan antar variabel bebas. Model regresi ganda yang baik adalah model yang terbebas dari gejala multikolinearitas yaitu dimana antar variabel bebas tidak saling berhubungan. Uji multikolinearitas ini menggunakan metode VIF (Variance Inflation Factor) dimana dasar pengambilan keputusan adalah dengan melihat nilai VIF dari hasil perhitungan dengan menggunakan bantuan aplikasi SPSS. Jika VIF lebih besar dari 10 maka terdapat gejala multikolinearitas.

Hipotesis pertama yang diuji adalah ada pengaruh signifikan Kinerja Pegawai (X1) terhadap Produktivitas Kerja Pegawai (Y). Pengujian hipotesis ini dilakukan dengan menggunakan analisis koefisien korelasi, uji signifikansi parameter model regresi, analisis koefisien determinasi, dan regresi linier sederhana. Berdasarkan hasil perhitungan dengan menggunakan SPSS diperoleh nilai koefisien korelasi $\mathrm{R}=0.730$ yang berarti bahwa ada korelasi yang kuat di antara kinerja pegawai dengan produktivitas kerja pegawai. Dengan menggunakan Uji-t didapatkan nilai thitung $=$ 7.989 yang lebih besar dari ttabel $=2.004$. Selain itu terlihat pula nilai signifikansi (Sig.) $=0.000$ yang lebih kecil dari $\alpha=0.05$ maka H0 ditolak dan H1 diterima artinya ada pengaruh yang signifikan antara motivasi kerja guru terhadap kinerja mengajar guru. Dari hasil analisis koefisien determinasi diperoleh nilai $\mathrm{R}$ square sebesar 
0.533. Nilai ini menunjukkan besarnya pengaruh Kinerja Pegawai (X1) terhadap Produktivitas Kerja Pegawai (Y) sebesar 53.3\%, sedangkan sisanya sebesar $46.7 \%$ dipengaruhi oleh faktor lain. Adapun dari analisis model regresi didapatkan persamaan model regresi:

$$
\widehat{Y}=0.735+0.801 X_{1} \ldots(2)
$$

Interpretasi dari persamaan di atas adalah apabila jika tidak ada kinerja pegawai atau $\mathrm{X} 1=0$, maka produktivitas kerja pegawai (Y) akan sebesar $\boldsymbol{a}=0.735$. Kemudian setiap penambahan nilai kinerja pegawai (X1) sebesar satu satuan, maka akan terjadi penambahan produktivitas kerja pegawai sebesar 0.801. Demikian pula untuk arah sebaliknya yaitu akan terjadi pengurangan sebesar 0.801 .

Hipotesis kedua yang diuji adalah ada pengaruh signifikan Komitmen Organisasi (X2) terhadap Produktivitas Kerja Pegawai (Y). Dengan cara yang sama dengan pengujian hipotesis pertama, diperoleh hasil sebagai berikut. Berdasarkan hasil perhitungan dengan menggunakan SPSS diperoleh nilai koefisien korelasi $\mathrm{R}=0.525$ yang berarti bahwa ada korelasi yang cukup kuat di antara komitmen organisasi dengan produktivitas kerja pegawai. Dengan menggunakan Uji-t didapatkan nilai thitung = 4.619 yang lebih besar dari ttabel $=2.004$. Selain itu terlihat pula nilai signifikansi (Sig.) $=0.000$ yang lebih kecil dari $\alpha=0.05$ maka $\mathrm{H} 0$ ditolak dan H1 diterima artinya ada pengaruh yang signifikan antara komitmen organisasi terhadap produktivitas kerja pegawai. Dari hasil analisis koefisien determinasi diperoleh nilai R Square sebesar 0.276. Nilai ini menunjukkan besarnya pengaruh Komitmen Organisasi (X2) terhadap Produktivitas Kerja Pegawai (Y) sebesar 27.6\%, sedangkan sisanya sebesar $72.4 \%$ dipengaruhi oleh faktor lain. Adapun dari analisis model regresi didapatkan persamaan model regresi:

$$
\widehat{Y}=1,891+0,471 X_{2} \ldots
$$

Interpretasi dari persamaan di atas adalah apabila jika tidak ada kmitmen organisasi atau X2 $=0$, maka produktivitas kerja pegawai $(\mathrm{Y})$ akan sebesar $\boldsymbol{a}=1.891$. Kemudian setiap penambahan nilai komitmen organisasi (X2) sebesar satu satuan, maka akan terjadi penambahan produktivitas kerja pegawai sebesar 0.471 . Demikian pula untuk arah sebaliknya yaitu akan terjadi pengurangan sebesar 0.471 .

Hipotesis ketiga yang diuji adalah ada pengaruh signifikan antara Kinerja Pegawai (X1) dan Komitmen Organisasi (X2) secara bersamasama terhadap Produktivitas Kerja Pegawai (Y). Berdasarkan hasil perhitungan dengan menggunakan SPSS diperoleh nilai koefisien korelasi $\mathrm{R}=0.803$ yang berarti bahwa ada korelasi yang sangat kuat antara kinerja pegawai dan komitmen organisasi dengan produktivitas kerja pegawai. Uji signifikansi parameter model regresi secara simultan dilakukan Uji-F didapatkan nilai Fhitung $=49.786$ yang lebih besar dari Ftabel $=$ 4.01. Selain itu terlihat pula nilai signifikansi (Sig.) $=0.000$ yang lebih kecil dari $\alpha=0.05$ maka $\mathrm{H} 0$ ditolak dan $\mathrm{H} 1$ diterima artinya secara bersamasama variabel kinerja pegawai dan komitmen organisasi berpengaruh signifikan terhadap produktivitas kerja pegawai. Dari hasil analisis koefisien determinasi diperoleh nilai $\mathrm{R}$ Square sebesar 0.644. Nilai ini menunjukkan besarnya pengaruh Kinerja Pegawai (X1) dan Komitmen Organisasi (X2) terhadap Produktivitas Kerja Pegawai (Y) sebesar $64.4 \%$, sedangkan sisanya sebesar 35.6\% dipengaruhi oleh faktor lain. Adapun dari analisis model regresi didapatkan persamaan model regresi:

$$
\widehat{\boldsymbol{Y}}=-0,002+0,694 X_{1}+0,312 X_{2} \ldots
$$

Interpretasi dari persamaan di atas adalah setiap penambahan nilai kinerja pegawai (X1) 
sebesar satu satuan, maka akan terjadi penambahan produktivitas kerja pegawai sebesar 0.694. Demikian pula untuk arah sebaliknya yaitu akan terjadi pengurangan produktivitas kerja pegawai sebesar 0.694. Kemudian, setiap penambahan komitmen organisasi (X2) sebesar satu satuan, maka akan terjadi penambahan produktivitas kerja pegawai sebesar 0.312. Demikian pula untuk arah sebaliknya, yaitu akan terjadi pengurangan sebesar 0.312 untuk setiap pengurangan satu satuan. Adapun nilai konstanta -0.002 diinterpretasikan bahwa jika tidak terdapat kinerja pegawai dan komitmen organisasi, maka tidak ada pula produktivitas kerja pegawai.

\section{PEMBAHASAN}

Kinerja dapat didefinisikan sebagai hasil kerja secara kualitas dan kuantitas yang dicapai seorang pegawai dalam melaksanakan tugasnya sesuai tanggung jawab yang diberikan (Mangkunegara, 2012, hlm. 9). Pengertian tersebut sejalan dengan penjelasan King (1993, hlm. 19, dalam Uno dan Lamatenggo, 2012, hlm. 61), kinerja adalah aktivitas seseorang dalam melaksanakan tugas pokok yang dibebankan kepadanya. Pengertian tersebut lebih diperjelas oleh Bernandin dan Rusel (Dunda, 2005:71) yang mengemukakan bahwa kinerja merupakan fungsi dan hasil dari suatu pekerjaan atau kegiatan tertentu selama satu periode waktu tertentu atau perwujudan dari hasil perpaduan yang sinergis dan akan terlihat dari produktivitas seseorang dalam melaksanakan tugas dan pekerjaannya. Begitupula dengan pendapat Veithzal Rivai Zainal, dkk (2014), kinerja merupakan perilaku nyata yang ditampilkan setiap orang sebagai prestasi kerja yang dihasilkan oleh karyawan sesuai dengan perannya dalam perusahaan. Berdasarkan pendapat dan konsep teori yang telah dikemukakan sebelumnya dapat diambil kesimpulan bahwa kinerja adalah fungsi atau hasil dari suatu pekerjaan yang dilaksanakan dalam periode waktu tertentu sesuai dengan peran dan tugas yang diberikan.

Secara umum, variabel kinerja pegawai memperoleh hasil perhitungan yang berada dalam kategori tinggi. Ini berarti kinerja pegawai sudah baik. Terdapat lima dimensi dalam variabel kinerja, yaitu kemampuan teknis, kemampuan konseptual, kemampuan hubungan interpersonal, kehadiran dan ketepatan waktu. Berdasarkan perhitungan WMS diketahui bahwa semua dimensi memiliki kategori tinggi. Dimensi tertinggi ada pada dimensi kemampuan konseptual dan kemampuan hubungan interpersonal. Sedangkan dimensi terendah adalah dimensi kehadiran.

Pada dimensi kemampuan teknis terdapat tiga indicator, yaitu kemampuan menggunakan pengetahuan, pengalaman yang diperoleh, dan pelatihan yang diperoleh. Indicator yang memiliki rata-rata tertinggi adalah kemampuan menggunakan pengetahuan, sedangkan indicator yang memiliki rata-rata terendah adalah indicator pelatihan yang diperoleh.

Kemampuan seseorang akan turut menentukan perilaku dan hasilnya, dimana ada seorang pegawai yang memiliki motivasi baik namun tidak memiliki kemampuan atau keterampilan yang diperlukan untuk melaksanakan tugasnya dengan baik (Prahesti, Djaelani, dan Choirul, 2017). Hal ini jelas akan menghambat terselesaikannya tugas yang diberikan dan harus diselesaikannya, serta akan menghambat tercapainya tujuan organisasi. Oleh karena itu, diperlukan usaha organisasi untuk meningkatkan dan mengembangkan kemampuan pegawai melalui 
pelatihan-pelatihan atau pendidikan-pendidikan sesuai dengan kebutuhan pegawai dalam menyelesaikan tugas-tugasnya agar mencapai tujuan organisasi.

Pada dimensi kemampuan konseptual hanya terdiri dari satu indicator, yaitu indicator memahami tugas dengan kategori tinggi. Pada dimensi kemampuan hubungan interpersonal terdiri dari dua indicator, yaitu indicator kemampuan bekerja sama dan indicator kemampuan memotivasi karyawan. Dari perhitungan WMS, diketahui bahwa kemampuan bekerja sama mempunyai nilai rata-rata indicator yang lebih tinggi daripada indicator kemampuan memotivasi karyawan. Motivasi berasal dari kata latin "movere" yang berarti dorongan atau daya penggerak (Prahesti, dkk, 2017). Menurut Basir (2016), motivasi kerja erat kaitannya dengan tindakan yang menyebabkan seorang pegawai mau bekerja dengan baik, ikhlas dan penuh semangat sehingga dapat tercapai hasil kerja yang maksimal.

Kemampuan memotivasi karyawan atau pegawai sangat diperlukan. Terutama kepada pegawai yang memiliki kinerja yang rendah. Kemampuan memotivasi ini bisa dimiliki dan dilakukan oleh sesama pegawai. Akan tetapi, sudah menjadi tugas dari pemimpin untuk memberikan perhatian lebih dalam memotivasi pegawai yang berada dalam tanggung jawabnya. Seperti yang telah dikemukakan oleh Edison, dkk (2017, hlm. 179) bahwa memotivasi adalah bagian pekerjaan manajerial dan harus dilakukan.

Pada dimensi kehadiran hanya terdiri dari satu indicator, yaitu indicator kehadiran di tempat kerja dengan kategori tinggi. Pada dimensi ketepatan waktu hanya terdiri dari satu indicator, yaitu indicator sesuai tidaknya dengan waktu yang direncanakan dengan kategori tinggi.

Dimensi kehadiran mendapatkan nilai ratarata dimensi terendah. Hal ini sudah dapat terllihat dari banyaknya pegawai yang tidak masuk kerja dengan tidak memiliki alasan di tahun 2016 dan tahun 2017, sesuai dengan data awal. Mengapa banyak pegawai yang tidak masuk kerja? Ada beberapa alasan yang menyebabkan seorang pegawai tidak dapat hadir, seperti karena sakit, kematian dalam keluarga dan alasan-alasan pribadi lainnya yang tidak dapat dihindari dan dapat dimengerti (Mathis dan Jackson, 2006, hlm. 123). Akan tetapi, ada juga ketidakhadiran yang dapat dihindari dan mempunyai unsur kesengajaan.

Ketidakhadiran sangat mahal dan berdampak tidak baik bagi organisasi (Mathis dan Jackson, 2006). Hal ini dapat berakibat pekerjaan dimana pegawai tersebut bekerja tidak akan selesai sehingga pegawai lain harus mendapatkan pekerjaan tambahan atau organisasi harus mempekerjakan pegawai tambahan.

Ketidakhadiran dapat dikendalikan atau dikurangi. Proses ini harus dimulai dengan pengawasan yang berkesinambungan atas statistik ketidakhadiran pada unit kerja sehingga atasan dapat mengetahui pegawai yang sering tidak hadir dan unit kerja mana yang memiliki ketidakhadiran berlebih dengan tepat (Mathis dan Jackson, 2006). Selanjutnya, atasan perlu memahami penyebab dari ketidakhadiran pegawai. Kebijaksanaan organisasi tentang ketidakhadiran ini perlu dinyatakan dengan jelas dalam buku pedoman, dimana untuk pegawai negeri sipil tertuang pada PP No. 53 tahun 2010 tentang disiplin pegawai negeri sipil. Dalam Peraturan Pemerintah tersebut tertulis pula tingkatan dan jenis hukuman disiplin yang dapat diberikan kepada PNS, yang dilakukan secara bertahap sesuai dengan tingkatan dan jenisnya atau sesuai dengan pelanggarannya.

Meyer dan Allen (dalam Luthans, 2006) mengemukakan komitmen organisasi adalah perasaan keterikatan seorang pegawai terhadap tempatnya bekerja. Sementara Kaswan (2016, hlm. 
126) berpendapat komitmen merupakan sikap kerja dalam wujud keinginan, kemauan, dedikasi, loyalitas, dan/atau kepercayaan yang kuat yang menunjukkan keinginan tetap menjadi bagian anggota organisasi dengan mau menerima nilai dan tujuan organisasi, dan bekerja atas nama/untuk kepentingan organisasi. Berdasarkan pemaparan tentang komitmen di atas, dapat diambil kesimpulan bahwa komitmen organisasi adalah suatu perasaan keterikatan dan sikap seorang pegawai terhadap tempatnya bekerja.

Berdasarkan perhitungan WMS diketahui bahwa variable komitmen sudah baik. Hal ini terlihat dari nilai rata-rata variable yang masuk kategori tinggi. Terdapat tiga dimensi pada variabel komitmen, yaitu dimensi komitmen afektif, dimensi komitmen normative, dan dimensi komitmen berkelanjutan. Berdasarkan perhiungan WMS, diketahui bahwa ketiga dimensi memiliki kategori tinggi. Dimensi yang memiliki nilai ratarata tertinggi adalah dimensi komitmen normative, selanjutnya dimensi komitmen afektif, sedangkan dimensi komitmen berkelanjutan memiliki nilai rata-rata terendah.

Pada dimensi komitmen afektif terdapat dua indicator, yaitu indicator keterikatan emosional dengan lembaga dan indicator yakin akan nilai-nilai lembaga. Berdasarkan perhitungan WMS diketahui bahwa indicator keterikatan emosional dengan lembaga mempunyai nilai ratarata indicator yang melebihi indicator yakin akan nilai-nilai lembaga. Kedua indicator tersebut memiliki kategori tinggi. Menurut Yeh dan Hong (2012), komitmen organisasi akan berdampak positif dan signifikan pada kinerja. Hal ini menunjukkan bahwa pegawai yang bersedia untuk tinggal dan mengabdi pada organisasi dikarenakan memiliki nilai yang sama dengan nilai-nilai yang ada pada organisasi tersebut.
Pada dimensi komitmen normative terdapat satu indicator, yaitu indicator kewajiban dengan lembaga. Berdasarkan perhitungan WMS, indicator ini mencapai nilai rata-rata indicator dengan kategori tinggi. Sedangkan pada dimensi komitmen berkelanjutan terdapat satu indicator, yaitu indicator imbalan ekonomi yang diperoleh. Berdasarkan perhitungan WMS, indicator ini mencapai nilai rata-rata indicator dengan kategori tinggi. Ini menunjukkan bahwa pegawai yang memiliki komitmen normative akan melaksanakan kewajiban pada lembaganya dengan baik. Komitmen normative mempunyai pengaruh positif dan signifikan terhadap kinerja pegawai (Ghorbanpour, Dehnavi, Heyrani, 2014).

Seperti yang telah dikatakan sebelumnya, bahwa dimensi komitmen berkelanjutan memiliki nilai rata-rata dimensi terendah. Dimensi komitmen berkelanjutan berhubungan dengan indicator imbalan ekonomi yang diperoleh. Seperti yang dikemukakan oleh Robbins \& Judge (2011), komitmen berkelanjutan berhubungan dengan imbalan ekonomi yang diperoleh.

Jika membicarakan imbalan ekonomi maka akan berkaitan erat dengan kompensasi yang diterima oleh pegawai. Menurut Sulistiyani, dkk (2009, hlm. 139), kompensasi adalah segala sesuatu yang diterima oleh pegawai sebagai balas jasa atas pekerjaan yang telah dilakukan. Kompensasi akan meningkatkan kepuasan kerja pada diri pegawai untuk lebih berkomitmen pada organisasi. Seperti yang dikemukakan oleh Gregson (2002, dalam Lestari dan Cahyono, 2003) bahwa kepuasan kerja adalah sebagai pertanda awal komitmen organisasi.

Menurut Nanang Fattah (1996:15; dalam Tjutju Yuniarsih dan Suwatno, 2016), konsep produktivitas berkembang dari pengertian teknis sampai dengan perilaku. Produktivitas dalam arti teknis mengacu pada derajat keefektifan dan 
efisiensi dalam penggunaan berbagai sumber daya, sedangkan dalam pengertian perilaku, produktivitas merupakan sikap mental yang senantiasa berusaha untuk terus berkembang. Pendapat ini sejalan dengan pandangan Saputra dan Muhidin (2011, hlm. 109) bahwa produktivitas kerja mengacu pada pendekatan sikap mental (attitude of mind) yang mempunyai semangat untuk melakukan peningkatan perbaikan. Dimana produktivitas kerja seseorang sesungguhnya merupakan gambaran dari dedikasi, loyalitas, disiplin, metode kerja yang dijalankan ketika menghadapi tugas dan beban kerjanya (Nawawi,1990, hlm. 90, dalam Tjutju Yuniarsih dan Suwatno, 2016, hlm. 163). Mengacu pada beberapa definisi yang telah dikemukakan tersebut, dapat diambil kesimpulan bahwa produktivitas kerja pegawai adalah sikap mental pegawai yang senantiasa berusaha untuk terus berkembang dan melakukan peningkatan perbaikan dalam menghadapi peran, tugas dan beban kerjanya sehingga menghasilkan suatu output kinerja yang tinggi.

Secara umum, produktivitas kerja pegawai jika dilihat dari hasil perhitungan mendapatkan skor rata-rata sebesar 3,60 yang termasuk dalam kategori tinggi. Hal ini menunjukkan bahwa ratarata produktivitas kerja pegawai sudah dapat dikatakan baik dalam bekerja. Terdapat tiga dimensi pada variabel produktivitas kerja pegawai, yaitu etos kerja, kualitas kerja dan kuantitas jumlah kerja. Berdasarkan perhitungan WMS, diketahui bahwa ketiga dimensi memiliki kategori tinggi. Akan tetapi, nilai WMS tertinggi ada pada dimensi etos kerja, diikuti dimensi kualitas kerja, sedangkan dimensi kuantitas jumlah kerja menjadi dimensi terendah.

Dalam dimensi etos kerja terdapat 7 indikator, yaitu kerja sebagai rahmat, kerja sebagai amanah, kerja sebagai panggilan, kerja sebagai aktualisasi, kerja sebagai ibadah, kerja sebagai seni dan kerja adalah kehormatan. Berdasarkan perhitungan WMS, diketahui bahwa semua indicator tersebut memiliki kategori tinggi. Indicator kerja sebagai rahmat memiliki rata-rata indicator tertinggi, sedangkan indicator kerja sebagai aktualisasi memiliki rata-rata indicator terendah.

Kerja sebagai aktualisasi mempunyai makna bekerja dengan penuh semangat agar dirinya diakui dalam lingkungan kerjanya untuk mencapai suatu kebutuhan. Jika aktualisasi diri rendah maka mempunyai arti bahwa ada kebutuhan lain yang lebih diutamakan oleh pegawai. Rizwan Saleem (2010, dalam Perveen dan Lodhi, 2015) mengemukakan bahwa kunci untuk memotivasi karyawan adalah mengetahui apa yang memotivasi dan merencanakan agenda motivasi berdasarkan kebutuhan tersebut. Selain itu, pengakuan formal atau sistem penghargaan telah terbukti efektif dalam meningkatkan motivasi pegawai.

Dalam teori motivasi Maslow (Gibson et al., 2012), kebutuhan untuk aktualisasi diri berada pada level tertinggi atau puncak dari kebutuhan seseorang, dimana kebutuhan-kebutuhan yang lainnya, yaitu kebutuhan fisiologis, kebutuhan rasa aman, kebutuhan rasa memiliki dan kasih sayang serta kebutuhan akan penghargaan telah terpenuhi. Meng-aktualisasikan diri dalam bekerja mempunyai arti mewujudkan potensi diri sendiri untuk menjadi sesuatu yang dapat dicapai oleh dirinya sendiri. Akan tetapi, gambaran kebutuhan aktualisasi diri tiap orang akan berbeda-beda, sesuai dengan penggambaran dan definisi aktualisasi dirinya masing-masing.

Dalam dimensi kualitas kerja terdapat 2 indikator, yaitu kerapian dan ketelitian. Berdasarkan perhitungan WMS, diketahui bahwa kedua indicator tersebut memiliki kategori tinggi dengan nilai yang sama besarannya. 
Dalam dimensi kuantitas jumlah kerja terdapat 2 indikator, yaitu prestasi kerja dan prakarsa. Berdasarkan perhitungan WMS, diketahui bahwa kedua indicator tersebut memiliki kategori tinggi. Akan tetapi, indicator prestasi kerja memiliki rata-rata indicator yang lebih tinggi daripada indicator prakarsa.

Prakarsa merupakan kemampuan pegawai dalam mengembangkan ide/gagasan dan tindakan yang dapat menunjang penyelesaian tugas yang diberikan kepadanya (Wirawan, 2014). Rendahnya prakarsa pada pegawai dapat terjadi karena berbagai faktor, misalnya pegawai tidak diberikan kesempatan untuk mengeluarkan atau mengemukakan ide/gagasannya, pegawai hanya ingin menerima perintah dari atasannya saja, atau karena kurangnya komunikasi antara bawahan dan atasan. Tetapi, rendahnya prakarsa juga bisa terjadi dikarenakan kompetensi yang kurang. Menurut Spencer dan Spencer (dalam Sumardjo, 2011), kompetensi adalah karakter sikap dan perilaku atau kemampuan individual yang relative bersifat stabil ketika menghadapi suatu situasi di tempat kerja yang terbentuk dari sinergi antara watak, konsep diri, motivasi internal serta kapasitas pengetahuan kontekstual. Jika kompetensi kurang maka akan berdampak pada pencapaian tujuan organisasi. Seperti yang telah dikemukakan oleh Mangkuprawira (2009) dimana kompetensi diperlukan oleh seorang pegawai untuk melakukan proses kerja dengan lancar secara efektif dan efisien dalam mencapai kinerja yang optimal. Kinerja yang optimal akan menunjang produktivitas kerja pegawai yang optimal pula.

Produktivitas kerja didukung oleh tingkat usaha yang dilakukan oleh pegawai dalam menampilkan kemampuan profesionalnya secara berkesinambungan, sesuai dengan tuntutan tugas yang diberikan kepadanya. Dengan demikian pengukuran produktivitas kerja pegawai selain berkaitan dengan tugas utamanya juga perlu dlihat dari sisi kualifikasi dan pengembangan profesionalnya (Yuniarsih dan Suwatno, 2016, hlm. 158). Oleh karena itu, untuk meningkatkan produktivitas secara umum, khususnya prakarsa dan aktualisasi diri, diperlukan peningkatan pendidikan dan keterampilan pegawai. Sebagaimana yang dikatakan oleh Sedarmayanti (2009) bahwa pekerjaan yang dilaksanakan dengan baik, disertai dengan pendidikan dan keterampilan yang sesuai akan mendorong kemajuan setiap usaha, yang pada gilirannya akan meningkatkan pendapatan, baik perorangan, kelompok, maupun nasional, termasuk di dalamnya adalah peningkatan produktivitas kerja pegawai dan produktivitas organisasi.

Produktivitas organisasi sangat ditunjang dan didukung oleh produktivitas kerja pegawai. Produktivitas kerja pegawai menjadi sangat penting bagi organisasi manapun karena akan berakibat pada produktivitas organisasi. Rendahnya produktivitas kerja pegawai membawa dampak bagi produktivitas organisasi dan diri pegawai itu sendiri.

Untuk mencapai produktivitas kerja yang maksimum, organisasi harus menjamin dipilihnya orang yang tepat, dengan pekerjaan yang tepat disertai kondisi yang memungkinkan mereka untuk bekerja optimal. Dengan kata lain, organisasi harus bisa memadukan antara keterampilan individunya dengan tuntutan pekerjaan (Arsen dan Mitchell, dalam Komalia, 2012). Pribadi yang produktif menggambarkan potensi persepsi dan kreativitas seseorang yang senantiasa ingin menyumbangkan kemampuannya agar bermanfaat bagi diri sendiri dan lingkungannya. Orang yang produktif adalah individu yang yakin akan kemampuan dirinya, yang dalam istilah sering disebut sebagai orang yang memiliki rasa percaya diri, harga diri, dan konsep diri yang tinggi. 
Werther dan Davis (1996, dalam Sumardjo, 2011), salah satu manfaat penilaian kinerja adalah productivity improvement, maksudnya dengan adanya umpan balik dalam pelaksanaan penilaian kinerja memungkinkan para pegawai, manajer, dan departemen personalia dapat mengetahui tindakan apa yang harus diambil untuk meningkatkan produktivitas kerja.

Berdasarkan hasil penelitian, diketahui terdapat pengaruh yang signifikan dari variabel kinerja pegawai terhadap produktivitas kerja pegawai. Hasil penelitian ini sejalan dengan penelitian Sumardjo (2011) yang menunjukkan adanya pengaruh yang positif dan signifikan dari penilaian kinerja terhadap produktivitas kerja. Begitu pula dengan penelitian yang telah dilakukan oleh Komariah (2014) dimana terdapat pengaruh langsung yang positif dan signifikan dari kinerja mengajar guru terhadap produktivitas sekolah dan terdapat pengaruh tidak langsung positif dan signifikan dari kepemimpinan transformasional dan iklim sekolah terhadap produktivitas sekolah melalui kinerja mengajar guru.

Banyak faktor yang dapat mempengaruhi produktivitas kerja. Secara umum, produktivitas suatu organisasi dipengaruhi oleh manusia, modal metode (proses), lingkungan organisasi (internal), produksi, lingkungan negara (eksternal), lingkungan internasional maupun regional dan umpan balik (Sinungan 2009, hlm. 56). Unsur manusia sebagai salah faktor yang mempengaruhi produktivitas kerja menyangkut beberapa hal antara lain, kuantitas, tingkat keahlian latar belakang budaya dan pendidikan, kemampuan, sikap, komitmen dan motivasi, disiplin, etos kerja, struktur pekerjaan, keahlian, umur (kadang-kadang jenis kelamin) dari angkatan kerja. Manusia memberikan kontribusi terhadap produktivitas kerjanya melalui kemampuan individualnya dan motivasi diri yang selanjutnya melahirkan komitmen organisasi.

Dari sekian banyak faktor yang mempengaruhi produktivitas, terdapat dua faktor yang menjadi variabel penelitian, yaitu komitmen dan kinerja. Hipotesis keenam adalah terdapat pengaruh yang signifikan antara variabel kinerja pegawai dan komitmen organisasi terhadap produktivitas kerja pegawai. Dari penelitian diketahui bahwa terdapat pengaruh yang signifikan secara simultan dari variabel kinerja dan komitmen terhadap produktivitas kerja pegawai.

Menurut Kaswan (2015, hlm. 47) komitmen mempengaruhi tingkat kinerja pegawai. Semakin tinggi komitmen pegawai terhadap tempatnya bekerja, maka akan semakin tinggi pula kinerja yang akan diberikan pegawai tersebut kepada organisasinya. Menurut Moris dan Sherman (1981, dalam Novita, dkk, 2016), komitmen organisasional berguna sebagai alat untuk melihat beberapa perilaku yang sangat penting, seperti kinerja, kehadiran di tempat kerja dan keluar masuknya karyawan dari organisasi. Dalam penelitiannya, Jawahar (2006) menemukan bahwa penilaian kinerja memainkan peran dalam hubungan antara kepuasan karyawan dan loyalitas karyawan. Penilaian kinerja merupakan hal yang penting dari unsur kesetiaan karena berhubungan positif dengan komitmen organisasi dan negative terkait dengan keinginan berpindah.

Mowday et.al (1982, dalam Sumardjo, 2011) menyatakan bahwa organisasi harus melakukan berbagai usaha untuk meningkatkan komitmen organisasional dalam diri pegawai karena semakin tinggi tingkat komitmen organisasional pegawai maka semakin lama ia ingin tetap berada dalam organisasi dan semakin tinggi pula produktivitas kerja yang dihasilkannya serta tingkat keluar masuknya pegawai akan semakin rendah. Akan tetapi menurut salah satu 
penelitian, tinggi rendahnya komitmen seorang pegawai tidak selalu dipengaruhi dengan berapa lamanya pegawai tersebut bekerja di organisasi tersebut (Kaswan, 2015, hlm. 50). Jadi, lama atau tidaknya seorang pegawai bekerja di suatu organisasi bukanlah salah satu tolok ukur tinggi atau rendahnya komitmen organisasi pegawai tersebut terhadap organisasi tempatnya bekerja.

Seberapa besar komitmen organisasi dan kinerja pegawai dapat mempengaruhi tinggi atau rendahnya produktivitas kerja pegawai. Dimana pada akhirnya, produktivitas kerja pegawai dapat mempengaruhi produktivitas organisasi. Pegawai yang memiliki kinerja dan komitmen yang baik secara bersama-sama akan meningkatkan produktivitas secara maksimal. Oleh karena itu, pegawai diharapkan memiliki kombinasi kerja yang baik dalam hal kinerja dan komitmen. Seperti yang dikatakan oleh Munir, dkk (2013) dalam penelitiannya bahwa persepsi keadilan penilaian kinerja telah mempengaruhi komitmen pegawai terhadap organisasi melalui faktor mediasi kepuasan agar tujuan organisasi tercapai. Demikian pula dengan yang dikemukakan oleh Edison, dkk (2017), bahwa pegawai yang memiliki komitmen yang tinggi terhadap organisasi akan menunjukkan kepuasan kerja yang terpenuhi sehingga dapat meningkatkan kinerja pegawai tersebut dan implikasinya adalah memudahkan untuk mencapai tujuan strategis organisasi. Begitu pula dengan penelitian Osa dan Amos (2014) yang menemukan bahwa komitmen organisasi memiliki dampak yang signifikan terhadap produktivitas karyawan dan dengan demikian meningkatkan kinerja dan efektivitas organisasi.

Ada berbagai cara untuk mempertahankan kinerja pegawai dan komitmen organisasi untuk meningkatkan produktivitas kerja pegawai. Onyeukwu dan Ekere (2018) menyarankan agar organisasi mengembangkan paket insentif yang lebih menarik untuk mendorong pegawai yang profesional dan berketerampilan tinggi agar tetap bertahan dan setia dalam organisasi. Sedangkan menurut Kibichii, Kiptum dan Chege (2016) untuk meningkatkan produktivitas pegawai, para pembuat kebijakan dan organisasi harus memastikan bahwa kinerja pegawai dinilai, pelatihan dan pengembangan dilakukan dan sistem penghargaan diberikan sesuai dengan ketentuan dan kebutuhan.

\section{SIMPULAN DAN REKOMENDASI}

Dalam upaya meningkatkan prakarsa pegawai saat bekerja, direkomendasikan untuk meningkatkan komunikasi organisasi antara pimpinan dan pegawai dan meningkatkan kompetensi pegawai. Meningkatkan kompetensi dan kemampuan pegawai, direkomendasikan untuk memberikan berbagai pendidikan dan pelatihan yang disesuaikan dengan kebutuhan dan ketentuan serta kebijakan organisasi. Menjadikan kerja sebagai aktuliasasi diri, direkomendasikan untuk memenuhi kebutuhan-kebutuhan lainnya seperti kebutuhan fisiologis, kebutuhan rasa aman, kebutuhan rasa memiliki dan kasih sayang dan kebutuhan akan penghargaan. Menjadikan kerja sebagai aktualisasi diri, direkomendasikan untuk memadukan dan menyesuaikan antara keterampilan yang dimilki pegawai dengan tuntutan pekerjaan yang diberikan. Meningkatkan kemampuan memotivasi, direkomendasikan kepada pimpinan untuk lebih memahami, memberi perhatian, dan berperan serta dalam memotivasi pegawai yang menjadi tanggung jawabnya. Mengontrol dan mengurangi ketidakhadiran pegawai, direkomendasikan kepada pimpinan 
untuk mencari penyebab dari ketidakhadiran pegawai dan melakukan tindakan disiplin sesuai dengan tahapan, kebutuhan, ketentuan dan kebijakan organisasi. Meningkatkan komitmen berkelanjutan, direkomendasikan kepada organisasi untuk memberikan kompensasi sesuai dengan hasil kerja dan ketentuan serta kebijakan organisasi.

\section{DAFTAR PUSTAKA}

Basir, M. A. (2016). Pengaruh Pendidikan dan Pelatihan, Motivasi Kerja terhadap Kualitas Pelayanan Dinas Kependudukan dan Catatan Sipil Kota Bau-Bau. Jurnal Ilmu Pemerintahan: Kajian Ilmu Pemerintahan dan POlitik Daerah. Vol. 1 (1), 85-106. DOI: 10.24905/jip.vlil.435.

Emron Edison, Yohny Amwar, dan Imas Komariyah. 2017. Manajemen Sumber Daya Manusia: Strategi dan Perubahan dalam Rangka Meningkatkan Kinerja Pegawai dan Organisasi. Bandung: Alfabeta.

Ghorbanpour, Zahra, Dehnavi, Hasan Deghan dan Heyrani Forough. (2014). Investigating The Effect of Organization Commitment on Performance of Auditors in The Community of Certified Accountants. Interdisciplinary Journal of Contemporary Research in Business. Februari 2014. vol. 5. no. 1.

Gibson, J. L., Ivancevich, J. M., James H. Donelly, J., \& Konopaske, R. (2012). Organizations abehavior, Structure, Processes (Fourteenth). New York: McGraw-Hill.

Jawahar, I. M. (2006). Correlates of satisfaction with performance appraisal feedback. Journal of Labor Research, vol. 27, issue 2, page: 213-236.

Kaswan. 2015. Sikap Kerja: dari teori dan implementasi sampai bukti.Bandung: CV. Alfabeta.

Kibichii, K. E., Kiptum, K. G., \& Chege, K. (2016). Effects of Performance Management Process on Employee Productivity: A Survey of Commercial Banks in Turkana County. IOSR Journal of Business and Management (IOS-JBM). e-ISSN: 2278-487X, p-ISSN: 2319-7668. Volume 18, Issue 11, Ver. IV (November, 2016), pp. 52-64. www.iosrjournal.org.

Komalia. (2012). Pengaruh Kualitas Lingkungan Sekolah Dan Motivasi Kerja Terhadap Produktivitas Kerja Guru Di Sekolah Menengah Pertama Negeri Sekota Bandung. Tesis. Bandung: Universitas Pendidikan Indonesia.

Komariah, Aan. (2014). Pengaruh Kepemimpinan Tranformasional, Iklim Sekolah, Kinerja Mengajar Guru terhadap Produktivitas Sekolah. MIMBAR Vol. 30, No. 1 pp. 118-
125, Juni, 2014. ISSN 0215-8175. EISSN 2303-2499.

Lestari, Evi dan Cahyono, Dwi. (2003). Komitmen Organisasi dan Kepuasan Kerja sebagai Mediasi Hubungan Profesionalisme denngan Intensi Keluar (Studi Empiris pada Internal Auditor Perusahaan Manufaktur di Indonesia). Simposium Nasional Akuntansi VI. 16-17 Oktober 2003.

Luthans, F. (2006). Perilaku Organisasi edisi 10. Terjemahan. Yogyakarta: Andi.

(2011). Organizational Behavior. Singapore: McGraw-Hill International Education.

Mathis, Robert L. dan Jackson, John H. (2006). Manajemen Sumber Daya Manusia. Alih Bahasa oleh Jimmy Sadely dan Bayu Prawira Hie. Jakarta: Salemba Empat.

Mangkunegara, Anwar Prabu. (2012). Evaluasi Kinerja SDM. Bandung: PT. Refika Aditama.

Novita, dkk. (2016). Pengaruh Kepuasan Kerja dan Komitmen Organisasional terhadap Kinerja Karyawan (studi pada PT. Telekomunikasi Indoensia, tbk Witel Jatim selatan, Malang). Jurnal Administrasi Bisnis (JAB). Vol. 34 No. $1 \quad$ Mei 2016. administrasibisnis.studentjournal.ub.ac.id. 38-46.

Onyeukwu, Pauline dan Ekere, Nikoyo Edet. (2018). Evaluation of Staff Motivation Strategies on The Productivity of Nigerian Banking Industry. International Journal of Innovation and Economic Development. Volume 4, Issue 1. April, 2018. pp: 51-59. ISSN 1849-7020 (print). ISSN 1849-7551 (online). DOI: $10.18775 /$ ijied.1849-75517020.2015.41.2005.

Osa, Igbaekemen Goddy dan Amos, Idowu Oluwafemi. (2014). The Impact of Organizational Commitment on Employees Productivity: A Case Study of Nigeria Brewery, PLC. IMPACT: International Journal of Research in Business Management (IMPACT: IJBRM). ISSN €: 2321-886X. ISSN (P): 2347-4572. vol. 2. issue 9. Sept 2014. pp: 107-122.

Peraturan Pemerintah Nomor 53 Tahun 2010 tentang Disiplin Pegawai Negeri Sipil 
Peraturan Pemerintah Nomor 46 Tahun 2011 tentang Penilaian Prestasi Kerja Pegawai Negeri Sipil (PNS).

Perveen, Saima dan Lodhhi, Samreen. (2015). The Effect of Motivation on Employee Productivity: A Case of Karachi, Pakistan. The International Journal of Business \& Management. Vol. 3. issue 11. November 2015. ISSN: 2321-8916.

Unit kerja pengembangan tenaga pendidik. (2016). Laporan Akuntabilitas Kinerja Instansi Pemerintah Unit kerja pengembangan tenaga pendidik Tahun Anggaran 2016. Bandung: Unit kerja pengembangan tenaga pendidik.

$$
\text { (2017). Laporan }
$$

Akuntabilitas Kinerja Instansi Pemerintah Unit kerja pengembangan tenaga pendidik Tahun Anggaran 2017. Bandung: PUnit kerja pengembangan tenaga pendidik.

(2018). Profil Lembaga

Unit kerja pengembangan tenaga pendidik Tahun 2018. Bandung: Unit kerja pengembangan tenaga pendidik.

Prahesti, Dian Ratih, dkk. (2017). Pengaruh Kemampuan, Motivasi dan Kinerja Pegawai terhadap Produktivitas Kerja (studi kasus pada Universitas Islam Malang). E-Jurnal Riset Manajemen Prodi Manajemen, Fakultas Ekonomi, Unisma. 18-29.

Robbins, Stephen P., dan Timothy A Judge. (2011). Organizational Behavior. New Jersey: Prentice-Hall Pearson Inc.

Saputra, Hatta dan Muhidin, Sambas Ali. Pengaruh Pemotivasian Kerja Dan Perilaku
Keorganisasian Terhadap Produktivitas Kerja Pegawai Pada Koperasi Pegawai Pemerintah Kota Bandung. Jurnal Manajerial Vol. 9, No. 18, Januari 2011 : 102 - 116.

Sulistiyani, Ambar Teguh dan Rosidah. (2009). Manajemen Sumber Daya Manusia Konsep, Teori dan Pengembangan dalam Konteks Organisasi Publik. Yogyakarta: Graha Ilmu.

Sumardjo, Mahendro. (2011). Pengaruh Penilaian Kinerja, Pengembangan SDM, Kompetensi, dan Komitmen Organisasional terhadap Produktivitas Kerja: Survei pada Auditor di Badan Pemeriksa Keuangan Republik Indonesia. Jurnal Strategic. Vo,ume 10, Nomor 19, Februari 2011, halaman 1-16.

Uno, Hamzah B., dan Lamatenggo, Nina. (2012). Teori Kinerja dan Pengukurannya. Jakarta: PT. Bumi Aksara.

Wirawan. (2014). Kepemimpinan Teori,Psikologi, Perilaku Organisasi, Aplikasi dan Penelitian. Jakarta: Rajagrafindo Persada.

Yeh, Hueryren dan Hong, Dachuan. (2012). The Mediating Effect of Organizational Commitment on Leadership Type and Job Performance. The Journal of Human Resource and Adult Learning. Vol. 8. Num. 2. Taiwan.

Yuniarsih, S dan Suwatno. (2016). Manajemen Sumber Daya Manusia: Teori, Aplikasi dan Isu Penelitian. Bandung: Alfabeta.

Zainal, Veithzal Rivai, dkk. (2014), Manajemen Sumber Daya Manusia untuk Perusahaan dari Teori ke Praktik. Edisi ketiga. Jakarta: PT RajaGrafindo Persada Rajawali Pers. 